\title{
Gulf-funding of British Universities and the Focus on Human Development
}

\author{
Jonas Bergan Draege \\ European University Institute, Italy \\ jonas.draege@eui.eu \\ Martin Lestra \\ European University Institute, Italy \\ martin.lestra@eui.eu
}

\begin{abstract}
We use quantitative content analysis to compare the academic publications and events of Gulf-funded Middle East research institutions in the uk to those that have not received such funding from a Middle Eastern donor. Our results provide some sup-port for hypotheses about funding leading to a bias in the selection of research topics. We show that Gulf-funding of uk Middle East Studies research institutions is associ-ated with less focus on democracy and human rights than non-funded comparable institutions. Moreover, we show that Gulf-funded institutions focus more on their donor countries than do non Gulf-funded institutions, but that they give more atten-tion to issues of education and youth unemployment than issues of democracy, human rights, and gender equality when writing about their donor countries.
\end{abstract}

\section{Keywords}

Higher Education - Gulf - the Arab Gulf - university funding - Arab Spring Human Development - universities - Arab Human Development Report

1 The authors share first authorship for this article. The order of names is made alphabetically.

2 The authors would like to thank Camille Brugier, Fernando Nuñez-Regueiro, AnnaMary O'Reilly, Daniel Schulz, Katharina Wolf and Alkistis Zavakou for their advice and comments during the work on this article. 


\section{Introduction}

After the Arab Spring, specialists of the Middle East were frequently criticised including by peers in their own area of study. While some critiqued the failure to predict the widespread uprisings, others targeted the neglect of central issues to do with the well-being of the citizens in the region, which were under-lying grievances that later surfaced with the events. 3 Central among these grievances were the growing frustrations among youth regarding the unjust, unfree, corrupt and nepotistic societies they were living in. However, these issues had already been addressed specifically in a pioneering policy-oriented study, the Arab Human Development Report (ahdr). 4 Shortly after the release of this report, during the second half of the 2000s, Arab Gulf countries increased flows of funding to British research institutions. Several of these Gulf donors claimed their involvement would secure new academic perspectives on Middle Eastern Studies.5 The oil-rich countries of the Gulf Cooperation Council (gcc) both created their own research institutions and university projects, and spent money on strengthening existing Middle Eastern Studies institutions abroad.6 This increase of funding was particularly strong in the United Kingdom where several of the most renowned centres of Middle Eastern Studies, with weak state support, gladly accepted funding streams from regional sources.

3 F. Gregory Gause, "Why Middle East Studies Missed the Arab Spring," Foreign Affairs, July/August 2011 http://www.foreignaffairs.com/articles/67932/f-gregorygause-iii/why-middle -east-studies-missed-the-arab-spring.

4 Adeel Malik and Bassem Awadallah, "The Economics of the Arab Spring," World Development 45 (2013): 296-313; Randall Kuhn, "On the Role of Human Development in the Arab Spring," Population and Development Review 38, no. 4 (2012): 649-83; Katerina Dalacoura, "The 2011 Uprisings in the Arab Middle East: Political Change and Geopolitical Implications," International Affairs 88, no. 1 (2012): 63-79; Larbi Sadiki, "Kudos to the undp for Arab Empowerment," Al Jazeera, 26 September 2011 http://www.aljazeera.com/indepth/ opinion/2011/09/201192685740453245.html; Mike Airosus, "After the Arab Spring: Toward Political \& Economic Inclusion in the Arab World (Event Summary)," Middle East Institute, 22 June 2011 http://www.mei.edu/events/afterarab-spring-toward-political-economic -inclusion-arab-world.

5 Alwaleed Bin Talal Foundation, "University of Edinburgh," Alwaleed Bin Talal Foundation, 27 October $2011 \mathrm{http} / /$ www.alwaleedfoundations.org/global/?project=/university-of edinburgh/; University of Exeter, "Centre for Gulf Studies - About us," University of Exeter (accessed $19 \quad$ November

2014) http://socialsciences.exeter.ac.uk/iais/research/centres/gulf/ about/.

6 For detailed list of funding from the Arab Gulf countries, see Appendix. 
This article investigates whether uk Middle Eastern Studies institutions that received funding from the Gulf were more attentive to the central issues of the Arab Human Development Report than other institutions before the Arab Spring, and if this balance changed after the uprisings. It does so by com-paring the academic output of uk Middle Eastern Studies institutions that received substantial funding from Gulf countries with uk Middle Eastern Studies institutions that were not funded by a Gulf donor. Finally, the article addresses the question of whether donations from the Gulf lead to any systematic bias of certain topics or countries.

\section{Background}

\section{The Arab Human Development Report (ahdr) and the Arab Spring} The ahdr was published in a series from 2002 to 2007 with the support of the United Nations Development Programme (undp). It was seen as a pioneer document in addressing long-neglected but pertinent issues of the region. The overall contention of the first ahdr report (2002) was that there were three urgent and pressing deficits facing Arab societies at large: freedom and democ-racy, education and youth unemployment, and women's empowerment. The overall contention that the region was "richer than it was developed" was par-ticularly clearly illustrated regarding the oil-rich Gulf countries. Three subse-quent reports were published in 2003, 2004, and 2005, each of them following up on one of the three deficits. Although widely noted for their quality, the reports did not seem at the time to have an immediate impact on the choice of topics in Middle Eastern Studies in the West.

When the Arab uprisings started in Tunisia in December 2010, and then spread to several other Arab countries in the following months, many Middle East scholars were caught by surprise. In an unprecedented fashion in the region, popular protests had erupted calling for the end of the oppressive rule and unjust societies. As Middle Eastern specialists in great numbers tried to identify reasons for the uprisings, the importance of the ahdr's three central issues were not lost on them.7 Campante and Chor highlighted particularly

7 E.g. Mohammad Al-Momani, "The Arab "Youth Quake": Implications on Democratization and Stability," Middle East Law and Governance 3, no. 1-2 (2011): 159-70; Michael Sakbani, "The Revolutions of the Arab Spring: Are Democracy, Development and Modernity at the Gates?," Contemporary Arab Affairs 4, no. 2 (2011): 127-47; Marc Lynch, "The Big Think Behind the Arab Spring," Foreign Policy, 28 November 2011 http://foreignpolicy.com/2011/11/28/ the-big-think-behind-the-arab-spring/. 
excessive state oppression and lack of freedoms, as well as educational and labour market deficiencies as being instrumental in sparking and sustaining the uprisings. 8 Hoffman and Jamal used the first wave of the Arab Barometer Survey to investigate the role of youth unemployment with the onset of the Arab Spring, and found much support for that claim.9 Gender was not generally considered an independently important factor in causing the Arab Spring. However, it was considered a central issue within the powerful calls for freedom and human rights.10 In short, many after-the-fact academic explanations identified freedom, knowledge and gender - which were highlighted in the three first Arab Human Development Reports - as core issues contributing to the Arab Spring.

Having been caught by surprise by the sudden turn of events, area specialists spent considerable energy on introspective criticisms of the whole field of Middle Eastern Studies shortly following the onset of the Arab Spring.11 Gause proposed that studies of the Arab World would have to be approached with renewed humility after the Arab Spring, and that this task would be better left to Arabs themselves.12 This perspective made the ahdr even stronger as a model. The fact that it had been a collaborative project led by mostly Arab intellectuals and researchers reinforced the idea that an increased involve-ment from the region itself in the field of Middle Eastern Studies would increase awareness of such issues.

\section{Gulf Donations: "New Voices" at British Universities}

Throughout the early 2000s, the oil-rich Gulf monarchies increased their funding of educational institutions in the West. This funding took a variety of

$8 \quad$ Filipe R. Campante and Davin Chor, "Why was the Arab World Poised for Revolution? Schooling, Economic Opportunities, and the Arab Spring," Journal of Economic Perspectives 26, no. 2 (2012): 167-88.

9 Michael Hoffmann and Amaney Jamal, "The Youth and the Arab Spring: Cohort Differences and Similarities," Middle East Law and Governance 4, no. 1 (2012): 168-88.

10 E.g. Nadje Al-Ali, "Gendering the Arab Spring," Middle East Journal of Culture and Communication 5, no. 1 (2012): 26-31.

11 Rex Brynen, "Arab Uprisings and the Study of Middle East Politics," Arab Uprisings: New Opportunities for Political Science (Washington, dc: Project on Middle East Political Science, 2012), 11-13; Eva Bellin, "The Robustness of Authoritarianism in the Middle East: Exceptionalism in Comparative Perspective," Comparative Politics 36, no. 2 (2004): 139-57; George Joffé, "The Arab Spring in North Africa: Origins and Prospects," The Journal of North African Studies 16, no. 4 (2011): 507-32; Jean-Pierre Filiu, The Arab Revolution: Ten Lessons from the Democratic Uprising (Oxford, uk: Oxford University Press, 2011); Gause 2011; Lynch 2011.

12 Gause 2011. 


\section{Gulf-funding of British Universities}

forms: from taking on entire responsibility for the creation and running of research centres connected to universities, to paying for academic chairs and fellowships, student scholarships, book publications and language courses, to smaller donations to archives and museums. In Europe, the inflow of Gulffunding increased particularly in uk research institutions. Although exact numbers are hard to come by as both donors and amounts are often kept discreet, some estimates suggest that private donations to Middle East Studies institutes could have almost tripled between the academic years 2004/2005 and 2006/2007.13 On the demand side, uk universities only received $37 \%$ of their revenues from government allocations in 2002, making the uk the only country in Europe where government funding did not make up a dominant source of revenues. 14 In addition, the uk government policy from 2008 was actively encouraging uk universities to seek private donations through its 'matched funding for voluntary giving' scheme.15

The Gulf foundations that fund uk research institutions argue that their contributions lead to closer relations between Western academia and the region itself and encourage new perspectives to come forward in the field.16 The Gulf Research Foundation, a uk registered charity working in close col-laboration with the Alwaleed Centre at Cambridge, claims to contribute to the promotion of new academic education programmes and Islamic perspectives in the social sciences.17 Some donors aspire to highlight the specific issues raised in the Arab Human Development Report. For example, the Emirates Foundation, which funds research centres at the London School of Economics (lse), the University of Wales Lampeter and Oxford, claims to have "researching, educating and informing on issues facing young people" as its key mission.18 The Qatar Foundation, a large donor to Oxford University's Centre for Islamic Studies, highlights its ambition to develop "a knowledge base in

13 Robin Simcox, A Degree of Influence: The Funding of Strategically Important Subjects in uk Universities (Surrey, uk: The Centre for Social Cohesion, 2009).

14 European Platform for Higher Education Modernisation (Modern), Funding Higher Education: A View Across Europe (Brussels: esmu - European Centre for Strategic Management of Universities, 2010).

15 hefce, "Matched Funding Scheme for Voluntary Giving 2008-2011," Higher Education Funding Council for England, May 2008 http://www.hefce.ac.uk/pubs/year/2008/c1112008/.

16 Alwaleed Bin Talal Foundation 2011; University of Exeter.

17 cso Net, "Gulf Research Center Foundation - About Us," ecosoc Civil Society Network (accessed $20 \quad$ November 2014) http://esango.un.org/irene/?page=viewProfile \& type=ngo\& nr=604528\&section=9.

18 Emirates Foundation, "Vision \& Mission," Emirates Foundation (accessed 19 November 2014) http://www.emiratesfoundation.ae/en/about-us/vision-mission. 
families and gender issues."19 The Gulf-funded universities also tend to justify their acceptance of funding by highlighting the possibility of gaining a closer understanding of the region.20 The Middle East Centre at the lse, which was established in 2006 thanks to a $£ 9$ million donation from the Emirates Foundation, states among its ambitions to "maintain close ties with Middle Eastern universities, scholars, policy makers, and civil society."21

The trend of Gulf funding to uk universities has sporadically been noted among academics and in the press, but to our knowledge no systematic study has so far examined the influence of this funding on the academic output of funded institutions. Some scholars have noted the potential soft power of phil-anthropic donations to research generally, and their potential to influence research topics, research questions, and methodologies in their attempts to mobilise the most promising academic intellectuals for a whole range of large-scale projects. 22 Regarding Gulf-funding to research in the uk specifically, Davidson has speculated on potential self-censorship and a loss of academic independence, noting that it is "hard to bite the hand that feeds."23 However, none of these studies have systematically investigated the extent to which such funding has an influence on the topics raised and the countries evaluated. In this article we try to empirically test the platform on which these claims are made. Our research questions are the following:

Research question 1: Were uk university-based Middle East institutions funded by the Gulf more attentive to issues raised by the ahdr before the Arab Spring than Middle Eastern Studies institutions funded exclusively by British sources?

19 Qatar Computing Research Institute, “Qatar National Research Strategy Report,” Qatar Foundation, 2012, 80 (accessed at: http://qcri.org.qa/resources/press-kit/qnrs).

20 The Alwaleed Centre, “About us - Overview," University of Edinburgh (accessed 20 November 2014) http://www.ed.ac.uk/schools-departments/literatureslanguages-cultures/alwaleed/ about.

21 1se Middle East Centre, "Constitution and Governance," London School of Economics and Political Science (accessed 19 November 2014) http://www.lse.ac.uk/middleEastCentre/ about/Constitution-Governance/Constitution\%20and\%20Governance.aspx.

22 Harold Joseph Laski, "Foundations, Universities and Research," The Dangers of Obedience \& Other Essays (New York: Johnson Reprint Corp., 1968), 171; Inderjeet Parmar, Foundations of the American Century: The Ford, Carnegie, and Rockefeller Foundations and the Rise of American Power (New York: Columbia University Press, 2013), 10; David Swartz, Culture and Power: The Sociology of Pierre Bourdieu (Chicago: University of Chicago Press, 1998), 101.

23 Christopher Davidson, "It's Hard to Bite the Hand That Feeds," Times Higher Education, 27 October 2011 http://www.timeshighereducation.co.uk/features/its-hard-to-bite-the -hand-thatfeeds/417909.article; Simeon Kerr, "Western Universities' Reputations at Stake in Gulf Links," Financial Times, 20 October 2013 http://www.ft.com/cms/s/0/7e8f1d8a-170d -11e39ec2-00144feabdc0.html\#axzz3jxla77du. 
Gulf-funding of British Universities

Research question 2: Did this balance change after the Arab Spring? Research question 3: When discussing ahdr issues, did Gulf-funded Middle

Eastern Studies institutions focus more or less on the donor country than non Gulf-funded institutions?

\section{Methodology}

\section{Data Collection}

Our data used for the analysis is the academic output published under the name of British research institutions focusing on the Middle East, from 2006 until 2014. That consists of:

- All academic publications (journal articles and books) advertised by the rel-evant research institution, from 2006-2014

- Titles and executive summaries of conferences organised under the name of the research institution or organized in association with the institution

The length of each abstract or title varied with the information provided by each institution, but we set a maximum limit of 300 words for each out-put unit. Descriptions and abstracts that went beyond this were cut at 300 words.

The data collection was done as comprehensively as possible, using the information available on institutions' websites, and contacting institutions directly. The sample used for this study is therefore vulnerable to an availability bias which tempers thereof the conclusions we draw from our analyses. We are aware of this, and therefore do not claim the sample to be representative of all Middle East Studies institutions. However, we do claim to have collected a sub-stantially large sample from the most influential uk university institutions. These are the institutions included in our sample:

Substantially Gulf-funded:24

- Middle East Centre (University of Oxford)

- The Alwaleed Centre (University of Cambridge)

- Center for Gulf Studies (University of Exeter)

- The Alwaleed Centre (University of Edinburgh)

24 See Appendix for table of donations made to uk universities 
- Institute for Middle Eastern and Islamic Studies (University of Durham)

- Middle East Centre (London School of Economics)

- London Middle East Institute (School of Oriental and African Studies)

Non Gulf-funded:

- Centre for Advanced Study of the Arab World (casaw)

- British Society for Middle Eastern Studies (brismes)

- Routledge's Middle East Studies Journals

We created a dictionary of keywords related to the three main issues of the ahdr: freedom, gender and knowledge. 25 We coded the titles, abstracts and descriptions using the software Yoshikoder. The coding counted the number of mentions of each of the ahdr topics for each of the research institutions. In order to parametrise the results of the word count for each journal, we created ratios of ahdr-related words, divided by the total word count in each journal. Each category among the ahdr-topics were calculated as ratios of the total number of ahdr-related words for each journal.

In the case of ambiguous codes, we double-checked the codings of the soft-ware by looking at the context of the abstracts that were coded. For the first two questions, we used this data to run ols regressions, testing interactions between two dummy variables, non Gulf-funded/Gulf-Funded, and pre/post Arab Spring. For the third research question, we used the software atlas.ti to identify each research output, and associate the mentions of the ahdr topics with the country or countries (Gulf donor or other Middle Eastern country) the academic output was concerned with. We then ran a keyword analysis to identify co- occurrences of references to donor countries and topics (freedom, gender and human rights). 26

\section{Results}

Research question 1: Were uk university-based Middle East institutions funded by the Gulf more attentive to issues raised by the ahdr before the Arab Spring than Middle Eastern Studies institutions funded exclusively by British sources?

25 See full dictionary in the Appendix.

26 For a more detailed account of methodological restrictions, see Appendix. 
Gulf-funding of British Universities

Table 1 ahdr topics before the Arab Spring

$\begin{array}{llll}\text { ahdr topics } & \text { Freedom and } & \text { Gender } & \text { Education and youth } \\ \text { combined } & \text { democracy } & \text { equality } & \text { unemployment }\end{array}$

\begin{tabular}{lllll}
\hline Gulf-funded27 & 0.011 & -0.027 & -0.225 & 0.263 \\
& $(0.013)$ & $(0.117)$ & $(0.107)$ & $(0.146)$ \\
Constant & 0.980 & 0.384 & 0.462 & 0.133 \\
& $(0.01)$ & $(0.165)$ & $(0.085)$ & $(0.117)$ \\
$R 2$ & 0.09 & 0.01 & 0.32 & 0.18 \\
$N$ & 11 & 11 & 11 & 11 \\
\hline
\end{tabular}

$* p<0.1 ; * * p<0.05 ; * * * p<0.01$

The regressions in table 1 show that before the Arab Spring, the academic outputs of institutions that were funded by the Gulf states were somewhat (1.1 percentage points) more likely to be concerned with the topics raised by the Arab Human Development Report than other institutions. When breaking down these trends to the three topics raised by the ahdr, we see that Gulffunded institutions were somewhat less likely to raise issues of democracy and human rights ( -2.7 percentage points), and much less likely to raise issues of gender ( -22.5 percentage points). Institutions funded by Gulf countries were however much more likely to raise issues of youth unemployment, and the development of knowledge and education in the region (26.3 percentage points), which resulted in the overall positive trend.

Research question 2: Did this balance change after the Arab Spring?

The regressions in table 2 show that after the Arab Spring, institutions funded by Gulf countries were no longer more likely to be concerned with the topics raised by the Arab Human Development Report than non Gulf-funded institutions.

When breaking down these trends to the three topics raised by the ahdr, we see that, in general, there was a substantial increase in attention paid to topics of democracy and human rights for both Gulf-funded and non Gulf-funded institutions. However, institutions funded by Gulf countries continued to be somewhat less likely to raise these issues than was the group of non Gulf-funded institutions ( -2.7 percentage points). There was a substantial increase

27 Gulf-funded is here a dummy variable where $0=$ not Gulf-funded and $1=$ Gulf-funded. 
Table 2 ahdr topics and the Arab Spring

\begin{tabular}{lllll}
\hline & $\begin{array}{l}\text { ahdr topics } \\
\text { combined }\end{array}$ & $\begin{array}{l}\text { Freedom and } \\
\text { democracy }\end{array}$ & $\begin{array}{l}\text { Gender } \\
\text { equality }\end{array}$ & $\begin{array}{l}\text { Education and youth } \\
\text { unemployment }\end{array}$ \\
\hline Gulf-funded & 0.011 & -0.027 & -0.225 & 0.263 \\
& $(0.013)$ & $(0.117)$ & $(0.107)$ & $(0.146)$ \\
Arab Spring28 & -0.002 & 0.122 & -0.132 & 0.007 \\
& $(0.015)$ & $(0.132)$ & $(0.120)$ & $(0.165)$ \\
Interaction & -0.003 & -0.175 & 0.352 & -0.180 \\
& $(0.018)$ & $(0.165)$ & $(0.151)$ & $(0.207)$ \\
Constant & 0.980 & 0.384 & 0.462 & 0.133 \\
& $(0.01)$ & $(0.165)$ & $(0.085)$ & $(0.117)$ \\
$R 2$ & 0.07 & 0.15 & 0.29 & 0.21 \\
$N$ & 22 & 22 & 22 & 22 \\
\hline
\end{tabular}

$* p<0.05 ; * * p<0.01$

in attention paid to issues of gender by Gulf-funded institutions after the Arab Spring (35 percentage points), while non Gulf-funded institutions focused less on gender after the Arab Spring ( -13 percentage points). The attention paid to issues of youth unemployment and education decreased significantly among Gulf--funded institutions after the Arab Spring (interaction effect of -18 per-centage points), but is compensated by the non Gulf-funded institutions after the Arab Spring, rendering the overall change negligible ( 0.7 percentage points).

Research question 3: Did Middle Eastern Studies institutions funded by Gulf countries focus more or less on the donor country in relation to issues raised by ahdr than did Middle Eastern Studies institutions funded exclu-sively by British sources?

Figure 1 reveals two trends. First, Gulf-funded institutions focused more on Gulf donor countries than non Gulf-funded institutions for all ahdr topics. For example, when Gulf-funded and non Gulf-funded institutions discussed gender issues, they linked this to the Gulf donor countries $21 \%$ and $10 \%$ of the time, respectively. Overall, Gulf-funded research institutions associated ahdr

Arab Spring is here a dummy variable where $0=$ pre-Arab Spring and $1=$ Post-Arab Spring. 
Gulf-funding of British Universities

Figure 1

\section{Discussing AHDR Topics}

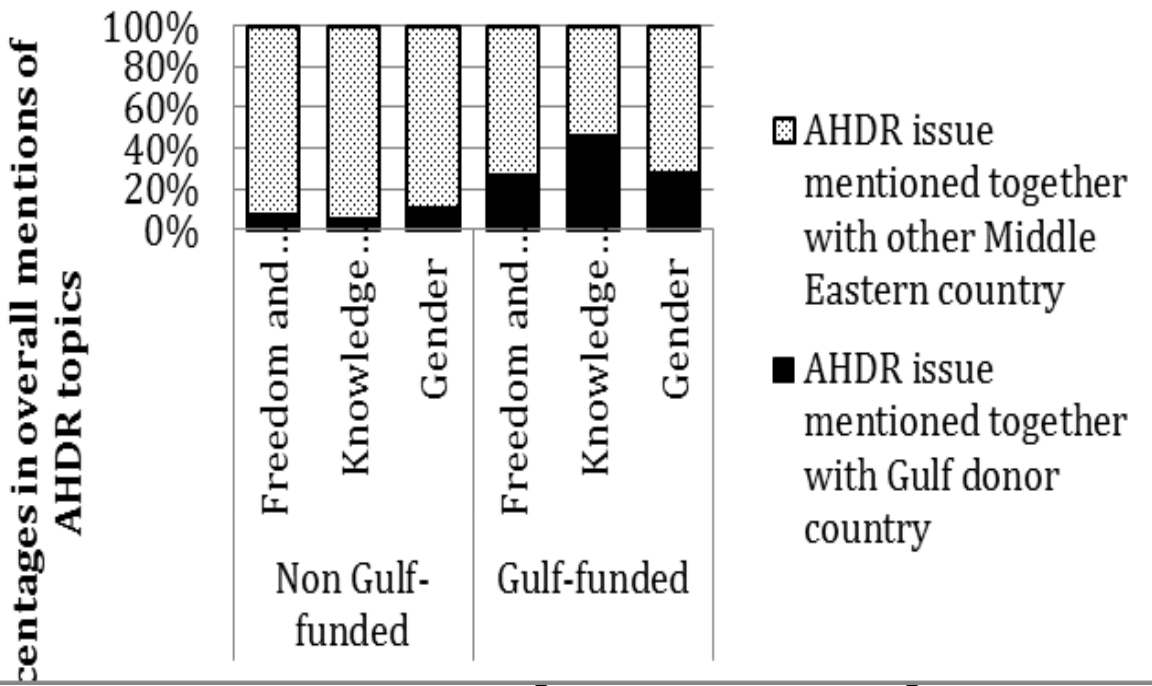

results indicate that Gulf-funded research institutions in the uk were much less likely to raise issues of gender equality and female empowerment, and somewhat less likely to raise issues of democracy and human rights, than non 
Gulf-funded institutions before and after the Arab Spring. The Arab Spring was associated with a sharp increase of attention to democracy and human rights in all institutions, although Gulf-funded institutions continued to give less attention to these issues than non Gulf-funded institutions. This is in line with the widespread narrative of the uprisings being anti-authoritarian and pro-democracy in their origins, and suggests that the Arab Spring did prompt insti-tutions to focus on these issues. Curiously, Gulf-funded institutions also substantially increased their focus on gender issues after the Arab Spring, whereas there was no increase in attention devoted to gender issues among non Gulf-funded institutions after the uprisings.

The fact that democracy and human rights were talked about less among Gulf-funded institutions than non Gulf-funded institutions may indicate a selective bias regarding issues that are known to be sensitive to donor countries. To be sure, when Gulf-funded institutions did talk about these issues, they were generally focusing more on their donor countries than did non Gulf-funded institutions. However, Gulf-funded institutions gave more attention to other countries in particular when discussing freedom and human rights - while they were equally inclined to discuss youth edu-cation and unemployment in other Middle Eastern countries as in Gulf donors' countries. This gives some empirical leverage to the hitherto anec-dotal speculations of the association between external private funding to academic institutions, and strategic selection - and omission - of sensitive research topics.

We make no claim of testing causal processes in this study. Our research does however show some strong correlational patterns, providing empiri-cal support for a much-speculated phenomenon. We therefore believe that this study is a promising first step for further research. In particular, we believe that the next natural step should be to test the causal relationship of funding. This can be done with a difference -in-differences research design, looking at the timing of the onset of Gulf funding, as well as con-solidated by conducting comparative in-depth content analysis of the characterization and framing of topics in Gulffunded and non Gulf-funded academic outputs. 


\section{Appendix}

\section{Data Collection, Dictionary Entries and Coding Instructions \\ Data and Data Collection29}

Our data used for the analysis is the academic output published under the name of British research institutions (think tanks are thus excluded from the scope of analysis) focusing on the Middle East, from 2006 until 2014. That con-sists of:

- All humanities and political science academic publications (journal articles and books, including forthcoming ones) advertised by the relevant research institution, from 2006-2014.30

- Titles and executive summaries of conferences organised under the

name of the research centre or organized in association with the centre.

The length of each abstract or title varied with the information provided by each institution, but we set a maximum limit of 300 words for each output unit. Descriptions and abstracts that went beyond this were cut at 300 words. This proce-dure guarantees feasibility (abstracts are more convenient to code than full articles); clarity (if an abstract is to summarize the article's main themes and findings, the main relevant topics ought to be mentioned therein); and equity (each unit had similar length, and therefore more likely to be comparable). When collecting data from conferences (in which organizers systematically state that participants' views do not reflect those of the institution itself), only conference titles and guidelines were considered - not participants' contributions. Book reviews were excluded from the analysis, while publications of affiliated research-ers were only taken from the institution's website.

Data collection was done as comprehensively as possible, using the information available on institutions' websites, and contacting institutions directly. The sample consists of 2,338 items, divided into the following categories:

29 In the data collecting process, names of researchers, speakers and organizers are not con-sidered. This work does not aim at targeting individuals, but at analysing academic out-put from various institutions, and to a limited extent, editorial or academic guidelines within Middle Eastern Studies.

30 'Islamic science' journals are excluded from this study. Despite dependence on available unstandardized qualitative data, this study focused on comparable outlets - in which de-contextualized theological debates, often necessitating Arabicspecific codes would ren-der investigation burdensome and results (potentially) skewed. However, the Arab Spring's impact on Islamic science output and debates is at first glance both attractive and unchartered territory for social science scholars. 
Table $1 \quad$ Number of academic outputs (abstracts of max. 300 words)

Pre-Arab Spring Post-Arab Spring TOTAL

\begin{tabular}{lrrr}
\hline Substantially Gulf-funded & 402 & 915 & 1317 \\
Non Gulf-funded & 597 & 424 & 1021 \\
TOTAL & 999 & 1339 & $\mathbf{2 3 3 8}$ \\
\hline
\end{tabular}

- Middle East Centre (University of Oxford)

- The Alwaleed Centre (University of Cambridge)

- Center for Gulf Studies (University of Exeter)

- The Alwaleed Centre (University of Edinburgh)

- Institute for Middle Eastern and Islamic Studies (University of Durham)

- Middle East Centre (London School of Economics)

- London Middle East Institute (School of Oriental and African Studies)

Non Gulf-funded:

- Centre for Advanced Study of the Arab World (casaw)

- British Society for Middle Eastern Studies (brismes)

- Routledge's Middle East Studies Journals

\section{Dictionary entries}

We created a dictionary of keywords of nearly 300 entries, all related to the three main issues of the ahdr: freedom, gender, and knowledge.31 Limitations to the dictionary's comprehensiveness may arise from several types of error:

- A word in the wrong category

- A word missing in one category

- A word present in more than one category

To overcome such obstacles, our dictionary has been constructed both deduc- tively (online library and thesaurus) as well as inductively (in particular, using the ahdr itself).

31 To our knowledge, thematic dictionary entries on freedom and democracy, youth and knowledge and gender are yet to be shared - hence any comments and contributions are welcome in upgrading the presented version. 
Furthermore, dictionaries may overlook the contexts in which one uses keywords or also define an inappropriate level of abstraction that may poten-tially mislead the investigation. Designing the dictionary therefore requires first to use keywords that are relevant and sufficiently defined. In the case of the freedom and democracy category, 'free press' will appear as a plausi-ble indication that the item deals with such issues, while 'free' is too broad to be considered as a keyword.

In addition, in the case of content analysis tools - such as Atlas.ti - the use of a quotation-based coding procedure, one might accept that the probability of 'prison' being mentioned simultaneously to 'authoritarian' or the like enables us to limit the number of keywords to be employed.

\section{Coding Procedure}

Coding proceeded through a quantitative approach (word and quotation count) in treating unstandardized qualitative data.32 For the first and second research questions, we coded the titles, abstracts and descriptions using the coding software Yoshikoder. The coding was based on word count, counting the number of mentions related to each of the ahdr topics for each of the research institutions. We used this data to run ols regressions with interactions over two dummy variables: non Gulf-funded/Gulf-Funded, and pre/post Arab Spring with the stata software. To avoid skewed results due to outliers, we dropped "under-1000 ahdr mentions" institutions.

For the third research question, we used the software atlas.ti to identify each research output, and associate the mentions of the ahdr topics with the country or countries (Gulf donor or other Middle Eastern country) the academic output was concerned with. The coding procedure is based on quotation count of a sam-ple of 2,338 collected items. One the one hand, one quotation suffices to code an item under one category. In other words, one item cannot be coded twice if two quotations pertaining to the same category appear in the same item (e.g., if "democracy" and "autocracy" appear in the same item, the latter will be coded only once in the category freedom). On the other hand, every item may be coded into different categories (e.g., an item may be coded under freedom and gulf donor and gender if quotations related to each of these categories appear simultaneously). This enables in particular to identify occurrences and co-occurrences of references to donor countries or topics (youth and unemployment, freedom and gender). In the case of ambiguous codes, we double-checked the codings of the software by looking at the context of the abstracts that were coded. 


\section{Institution \\ Size of \\ Donor \\ Stated purpose \\ Year \\ donation}

Middle East Centre, University $£ 1$ million

King Abdul Aziz

Foundation

of Oxford

Oriental Institute,

University of Oxford

$£ 1.5$ million

The Zayed Bin Sultan Al Nahayan

Charitable and Humanitarian

Foundation of the United Arab

\section{Emirates}

Ashmolean Museum,

University of Oxford

University of Oxford

$£ 2 \mathrm{~m}$

Saudi Prince Sultan Salman bin

Abdul Aziz al-Saud

Unknown Qatar

Foundation

Oxford Centre for

Islamic Studies

Oxford Centre for

Islamic Studies
$£ 20$ million

$£ 2.5$ million

King Fahd of

Saudi Arabia

Kuwait Foundation for the

Advancement of

Sciences
Running of the Middle East

2001

Centre archive

To establish a new lectureship in 2005

Islamic Studies

Construction of the museum

2005

Establish the Emir Sheikh Hamad

2008

Bin Khalifa al- Thani Chair in

Contemporary Islamic Studies

Construction of new buildings

1997

Kuwait International Programme

1997 
Oxford Centre for

Islamic Studies

Faculty of Oriental Studies,

University of Cambridge

Faculty of Oriental Studies,

University of Cambridge

University of Cambridge

University of Edinburgh

London Middle East Institute, $£ 1.25$ million soas

Centre for Middle Eastern

$£ 9 \mathrm{~m}$

Studies, the London School of

Economics (lse)

lse

$£ 5.7 \mathrm{~m}$ estimated

$£ 75$ million’

$£ 2.8$ million

$£ 300,000$

$£ 8$ million

$£ 8$ million
Twelve Islamic countries, including Malaysia, Turkey, Yemen, uae and Brunei Sultan Qaboos bin Said, the Sultan of Oman

Sultan Qaboos bin Said, the Sultan of Oman

Prince Alwaleed bin Talal of Saudi Arabia

Prince Alwaleed bin Talal of Saudi Arabia

Sheikh Mohamed bin Issa Al Jaber

Emirates Foundation

Kuwait Foundation for the

Advancement of Sciences
Materials for construction of

Ongoing

buildings

To establish a Professorship of

Modern Arabic, known as the 'His

Majesty Sultan Qaboos bin Said

Professorship of Modern Arabic'

To support a Fellowship

To fully finance the Centre

To fully finance the Centre

To help finance the establishment

2001 of the institute

To establish and construct the

Centre

To establish the 'Kuwait Programme on Development,

Governance and Globalisation in the Gulf States' 
University of Durham

University of Exeter

University of Exeter

University of Exeter

$£ 700,000$

University of Exeter

$£ 650,000$

University of Exeter

$£ 750,000$

$£ 2.4 \mathrm{~m}$

$£ 2.25$ million

Sultan bin Mohammed al-Qasimi, ruler of Sharjah

Sheikh Rashid bin Saeed al- Maktoum, ruler of Dubai Sheikh Sultan bin Mohammed al-Qasimi, ruler of Sharjah

Prince Alwaleed bin Talal of Saudi Arabia

Sheikh Sultan bin MohammedalQasimi, ruler of Sharjah

$£ 1$ million

Sheikh Sultan bin Mohammed
To construct a new building for

1999

the Institute of Middle Eastern

and Islamic Studies (imeis)

The university library

1984

Funded the construction of the

Institute of Arabic \& Islamic

Studies

Part of a campaign to'bridge the

gap between the Islamic and western worlds' following 9/11

To pay for an extension to the Institute of Arab and Islamic Studies building Towards a project to redevelop al-Qasimi, ruler of Sharjah 
Once keyword analysis was run, codes were merged into categories to have an overview of the distribution of categories across the entire data sample. Hence, if 'free press' and 'fair trial' were coded as $(1+1)$, merging codes allocate them only one code (1). In order to fully answer the third research question, we collapsed Middle Eastern countries into two categories: that of Gulf donors (Kingdom of Saudi Arabia, Qatar, United Arab Emirates, Oman, Kuwait), and thus excluding other Gulf states such as Yemen or Iraq; and the other encom-passing all Middle Eastern countries.

Indicative Figures of Gulf funding in British universities Unsurprisingly, foreign funding in the United Kingdom is researched exten-sively by those who are suspicious of or oppose this practice. Gulf funding in British universities has spurred comments and reports by the Center for Social Cohesion and Civitas, both right-leaning institutions from which we have com-piled our own data.

Arab Human Development-Based Dictionary Entries34

- Freedom

- Authoritarianism

- Authoritarian*

- Autocra*

- Brutal*

- Despot*

- Dictator ${ }^{*}$

- Disciplinar*

- Domineer*

- Draconi*

- Heavy-handed

- High-handed*

- Illiberal $^{*}$

- Imperious*

- Iron-fisted*

- Military regime

- Oppress*

- Repress ${ }^{\star}$

$34 \quad$ The symbol * is used to indicate to the software Yoshikoder that it should look for all varieties of the word. For example, the spelling democra* prompts the software to look for democracy, democracies, democratic, democratization, and so on. 
- Ruthless

- Strict*

- Totalitarian*

- Tyran*

- Undemocra*

- Democratization

- Citizen participation

- Civic association*

- Civil government

- Civil libert*

- Civil politic*

- Civil society

- Civilised polit*

- Civilized polit*

- Coalition government*

- Constitut*

- Constitution*

- Contentious politic*

- Debate

- Democra*

- Democratic society

- Direct demo*

- Diversity

- Division of branches

- Fair elections

- Free and fair elections

- Free broadcasting*

- Free elections

- Free media*

- Free press

- Freedom index

- Freedoms

- Independent media*

- Independent newspaper*

- Independent press

- Indirect demo*

- Individual freedom*

- Law*

- Liberal democra*

- Liberal government* 
- Media freedom*

- minority right*

- Opposition*

- Parliamentarism*

- political concession*

- political cultur*

- political dialogue*

- political inclusi*

- Political liberalisation*

- Political liberalization

- Political reform*

- Political rights

- Political transit*

- Politically inclusi*

- Power shar*

- Power-shar*

- Press freedom*

- Pro-demo*

- Public meeting

- Representative demo*

- Respect for right*

- Rule of law

- Separation of powers

- Social inclusi*

- Social just*

- Socially inclusi*

- Suffrage*

- Trade union*

- Human Rights

- Capital Punish*

- Citizen*

- Citizens' right*

- Civil libert*

- Civil right*

- Constitutional right*

- Death by hang*

- Death penalt*

- Education right*

- Educational right*

- Electric chair 
- Execution*

- Freedom from fear*

- Freedom of consciousness*

- Freedom of expression*

- Freedom of religion*

- Freedom of speech*

- Freedom of worship*

- Guillotine*

- Human right*

- Human securit*

- Individual right*

- Legal right*

- Natural right*

- Religious freedom*

- Right to education

- Right to vote*

- Rights of education

- Rights of women

- Social right*

- Uncivil*

- Universal declaration of right*

- Vot*

- Women's rights

- Gender

- *Patriarch*

- cedaw

- Coerced into sex

- Convention on the Elimination of All Forms of Discrimination against Women

- Differences between sexes

- Differences between the sexes

- Discrimination against women

- Discrimination against women

- Discrimination between the sexes

- Discrimination on the basis of race or sex

- Domestic abuse*

- Domestic violen*

- Education of women

- Emancip*

- Empowerment of women 
Gulf-funding of British Universities

- Family law*

- Fem*

- Female circumcision

- Female education

- Female empowerment

- Female genital mutilation

- Female infection

- Femin*

- Forced marriage*

- Gay

- Gender*

- Homosexual*

- Kidnapping of women

- Lesbian*

- $\operatorname{lgbt}$

- Mascul*

- Mixing of the sexes

- Rape

- Rapist*

- Relationship between men and women

- Sex difference*

- Sexual abuse*

- Sexual assault*

- Sexual degradation*

- Sexual discrimination*

- Sexual harassment*

- Transsexual

- Violence against Women

- Women-friendl*

- Women's

- Youth

- Knowledge

- Application of knowledge*

- Cumulative knowledge

- Deficit in knowledge*

- Deficit of knowledge*

- Deficits in knowledge*

- Deficits of knowledge*

- Educat*

- High school ${ }^{*}$ 
- Higher educ*

- Knowledge acquisition

- Knowledge application*

- Knowledge block*

- Knowledge capital

- Knowledge deficit ${ }^{\star}$

- Knowledge diffusion*

- Knowledge exchange

- Knowledge gap

- Knowledge indicator*

- Knowledge production*

- Knowledge society

- Knowledge worker*

- Knowledge-based society

- Primary educ*

- Primary school*

- Production of knowledge

- Schooling*

- Secondary educ*

- Secondary school*

- Universit*

- Youth employment and social mobility

- Class mobilit*

- Delayed marriage

- Economic mobilit*

- Educational mobilit*

- Employabilit*

- Employment opportunit*

- Generation*

- Generational mobilit*

- Gerontocrac*

- Intergenerational mobilit*

- Labour mobilit*

- Mobility pattern*

- Occupational mobilit*

- Opportunities of employment

- Pattern of mobilit*

- Patterns of mobilit*

- Skills gap* 
Gulf-funding of British Universities

- Social mobilit*

- Social status*

- Transition of young people

- Transition of youth

- Transition to adulthood

- Transitions of youth

- Transitions to adulthood

- Upward class mobilit*

- Upward mobility

- Upward social mobilit*

- Work transition*

- Youth bulge*

- Youth employment

- Youth potential*

- Youth unemployment

- Youth unemployment* 